\title{
ВИЗНАННЯ ПОКАЗАНЬ ІЗ ЧУЖИХ СЛІВ ДОКАЗОМ У КРИМІНАЛЬНОМУ ПРОЦЕСІ УКРАЇНИ
}

\author{
Пономаренко А. В., Гаврилюк Л. В.
}

\section{ВСТУП}

За кримінальним процесуальним законодавством України одним із видів доказів $є$ показання учасників кримінального провадження. Згідно 3 ч. 1 ст. 95 Кримінального процесуального кодексу України (КПК України) під показаннями слід розуміти відомості, які надаються в усній або письмовій формі під час допиту підозрюваним, обвинуваченим, свідком, потерпілим, експертом тощо щодо відомих їм обставин у кримінальному провадженні, які мають значення для досудового розслідування. Проте слідчому під час збору доказів, зокрема показань, необхідно врахувати, що згідно з ч. 4 ст. 95 КПК України суд може обгрунтовувати свої висновки лише на показаннях, які він безпосередньо сприймав під час судового засідання або отриманих у порядку, передбаченому ст. 225 КПК України, і суд не вправі обгрунтовувати судові рішення показаннями, наданими слідчому, прокурору, або посилатися на них. Що цілком узгоджується 3 п. 1 ст. 6 Конвенції про захист прав людини і основоположних свобод, де зазначено, що за відсутності суттєвих підстав для протилежного, поняття справедливого судового розгляду вимагає надавати більшого значення свідченням, наданим у суді, порівняно з протоколами допитів свідків на досудовому слідстві, оскільки останні являють собою передусім процес збору стороною обвинувачення інформації на підтримку своєї позиції ${ }^{1}$.

3 урахуванням цього органи досудового розслідування та сторона захисту і потерпілий зацікавлені в отриманні доказів із першоджерел, коли особа особисто сприймала факти, що мають значення для кримінального провадження, із первинних джерел інформації (ст. 91 КПК України). Такі докази належать до числа більш надійних, оскільки до мінімуму зводиться кількість носіїв фактичних даних і їх інтерпретаторів. Такі властивості первинних доказів зменшують вплив суб'єктивного чинника і надають їм більш переконливого характеру ${ }^{2}$.

\footnotetext{
${ }^{1}$ Конвенція про захист прав людини і основоположних свобод : підпис. 4 лист. 1950 р., м. Рим ; ред. від 02 жовт. 2013 р. ; ратифіковано Законом України від 17 черв. 1997 р. № 475/97-ВР. / Верховна Рада України. URL: https://zakon.rada.gov.ua/laws/show/995_004 (дата звернення: 21.05.2020).

Науково-практичний коментар Кримінально-процесуального кодексу України. URL: http://mego.info/\%D0\%BC\%D0\%B0\%D1\%82\%D0\%B5\%D1\%80\%D1\%96\%D0\%B0\%D0\%BB/\%D1\%81\%D1 \%82\%D0\%B0\%D1\%82\%D1\%82\%D1\%8F-97-\%D0\%BF\%D0\%BE\%D0\%BA\%D0\%B0\%D0\%B7\%D0\%B0\%
} 
За загальним правилом особа дає показання лише щодо фактів, які вона сприймала особисто. Проте після закріплення в КПК України інституту показань з чужих слів ст. 97 КПК України має винятки із загального правила допиту учасників кримінального провадження й передбачає один із видів доказів - показання з чужих слів.

Інститут показань 3 чужих слів $\epsilon$ новелою для вітчизняного кримінального процесуального законодавства, оскільки положення КПК України 1960 р. не передбачали такого різновиду доказів.

Водночас для того, щоб всебічно осмислити правові засади визнання показань з чужих слів доказом, зрозуміти сутність і призначення такого інституту, а також для забезпечення його належного впровадження в практичних умовах, необхідним $\epsilon$ правовий аналіз національного та міжнародного законодавства, яке регламентує підстави, порядок і наслідки визнання таких доказів допустимими у кримінальному провадженні.

Окремими питаннями допустимості показань 3 чужих слів як процесуального джерела доказів у кримінальному процесі України займалися такі вчені: В. Король, Г. Крет, В. Лушпієнко, А. Панова, О. Переверза, Т. Садова, Н. Скідан, О. Точиловський та інші. Проте, незважаючи на внесок зазначених науковців у дослідження цієї проблематики, нині залишаються невирішеними низка важливих теоретичних і практичних проблем інституту показань 3 чужих слів 3 необхідністю розроблення рекомендацій і пропозицій правового, організаційного та прикладного характеру.

\section{1. Правові засади визнання показань з чужих слів доказом}

Згідно 3 ч. 1 ст. 97 КПК України показаннями 3 чужих слів $\epsilon$ висловлювання, здійснене в усній, письмовій або іншій формі, щодо певного факту, яке грунтується на поясненні іншої особи. За правилами ч. 2 ст. 97 КПК України суд має право визнати допустимим доказом показання з чужих слів незалежно від можливості допитати особу, яка надала первинні пояснення, у виняткових випадках, якщо такі показання $\epsilon$ допустимим доказом згідно з іншими правилами допустимості доказів.

Варто зазначити, що закріплення в КПК України інституту показань 3 чужих слів зумовлене процесуальними реаліями та необхідністю вдосконалення процесу доказування. Але питання визнання доказом показань 3 чужих слів натепер серед практичних працівників та вчених $\epsilon$ досить спірним і має низку розбіжностей щодо його розуміння та застосування. Така законодавча новела викликала широку наукову та практичну дискусію. 3 цього приводу В. Король і Т. Садова констатують,

D0\%BD\%D0\%BD\%D1\%8F-\%D0\%B7-\%D1\%87\%D1\%83\%D0\%B6\%D0\%B8\%D1\%85-\%D1\%81\%D0\%BB $\% \mathrm{D} 1 \% 96 \% \mathrm{D} 0 \% \mathrm{~B} 2$ (дата звернення: 01.04.2020). 
що не всі положення нового кримінального процесуального законодавства отримали схвальну оцінку серед вітчизняних учених і практиків, окремі 3 них, на кшталт інституту показань з чужих слів, піддаються серйозній критиці. Новим є і сам інститут показань у тому вигляді, в якому він регламентований у новому КПК України ${ }^{3}$.

Слід відзначити, що більшість спеціалістів у галузі права до нового інституту показання $з$ чужих слів ставляться критично, адже вважають використання чуток, якими можуть бути показання 3 чужих слів, неприпустимим під час розслідування злочинів, оскільки обвинувачення повинне грунтуватися на доказах, достовірність яких можна перевірити. Отже, одні автори вважають цю норму закону необхідною в доказуванні, другі наполягають на їі вдосконаленні, а треті виступають за їі виключення з чинного КПК України.

Є думка, що існування у чинному КПК України такої законодавчої конструкції, як показання $з$ чужих слів, не сприяє встановленню істини у справі, оскільки особа, яка даватиме показання з чужих слів, не може нести відповідальність за їх неправдивість, а використання чуток, якими за своєю суттю можуть бути показання 3 чужих слів, $\epsilon$ неприпустимим під час розслідування злочинів, оскільки обвинувачення має грунтуватися на доказах, достовірність яких можна перевірити ${ }^{4}$.

Правники також акцентують увагу на тому, що застосування ст. 97 КПК України створює потенційну вразливість прав і свобод людини, гарантованих Конституцією України, Загальною декларацією прав людини ООН, Конвенцією Ради Свропи про захист прав людини і основоположних свобод.

У зв’язку з численними критичними зауваженнями 28 січня 2013 року у Верховній Раді України під № 2112 був зареєстрований проєкт Закону «Про внесення змін до Кримінального процесуального кодексу України», яким запропоновано виключити ст. 97 К КПК України, положення якої фактично дають змогу здійснювати кримінальне провадження, базуючись у тому числі на чутках та плітках 5 .

Зокрема, таке неоднозначне ставлення до процесуальної регламентації показань з чужих слів, як слушно зазначає О. Переверза, зумовлене

\footnotetext{
${ }^{3}$ Король В., Садова Т. Показання як джерело доказів у кримінальному провадженні. Науковий вісник Дніпропетровського державного університету внутрішніх справ. Дніпропетровськ. 2013. № 3. С. 428.

4 Комітет 3 питань верховенства права та правосуддя рекомендує парламенту направити на доопрацювання проєкт закону про внесення змін до Кримінального процесуального кодексу України (щодо виключення положень про визнання доказами показань 3 чужих слів). URL: https://rada.gov.ua/fsview/78466.html (дата звернення: 07.04.2020).

5 Про внесення зміни до Кримінального процесуального кодексу України (щодо виключення положень про визнання доказами показань з чужих слів): проєкт Закону України від 28.01.2013 р. № 2112. URL: https://ips.ligazakon.net/document/view/jg1mo00i?ed=2013_01_28 (дата звернення: 26.05.2020).
} 
особливостями механізму формування таких показань ${ }^{6}$. Унаслідок недосконалого правового регулювання інституту показань з чужих слів та відсутності належного механізму його реалізації виникають певні труднощі у процесі доказування.

Водночас, незважаючи на те, що порядок використання показань 3 чужих слів під час досудового розслідування та розгляду справи в суді має низку неузгодженостей, що зокрема викликає низку питань у практичній діяльності слідчих, такий законопроєкт тоді був передчасний. Про що засвідчує зміст ст. 97 КПК України, в якій передбачено, що у разі прийняття рішення про допустимість доказів показань 3 чужих слів суд зобов'язаний враховувати низку обставин, серед яких: 1) значення пояснень і показань у разі їх правдивості для з'ясування певної обставини i їх важливість для розуміння інших відомостей; 2) інші докази щодо питань, передбачених п. 1 ч. 2 ст. 97 КПК України, які подавалися або можуть бути подані; 3) обставини надання первинних пояснень, які викликають довіру щодо їх достовірності; 4) переконливість відомостей щодо факту надання первинних пояснень; 5) складність спростування пояснень, показань 3 чужих слів для сторони, проти якої вони спрямовані; 6) співвідношення показань 3 чужих слів з інтересами особи, яка надала ці показання; 7) можливість допиту особи, яка надала первинні пояснення, або причини неможливості такого допиту.

Тому ми поділяємо думку тих науковців, які вважають доцільним i можливим існування інституту показань 3 чужих слів 3 його доопрацюванням й удосконаленням. Вважаємо, що в деяких випадках слідчий просто не може обійтися без показань із чужих слів. Особливо на початку досудового розслідування по кримінальному провадженню, коли ще не встановлені всі свідки кримінального правопорушення, наявні певні причини (смерть, тяжкі травми учасників кримінального провадження тощо), які унеможливлюють їх допит, а слідчому на такому етапі необхідно прийняти низку рішень 3 кримінального провадження, зокрема обрання запобіжного заходу підозрюваному, призначення експертизи, проведення слідчих дій тощо. Прикладом тому також може стати ситуація, коли потерпілий на питання лікаря швидкої допомоги, який прибув на виклик за фактом спричинення особі тяжких тілесних ушкоджень, називає особу, яка заподіяла йому ці ушкодження і згодом помирає. У цьому разі, коли первинний доказ втрачений і його неможливо отримати, пояснення лікаря про існування факту, який особа не сприймала особисто, а дізналася

\footnotetext{
${ }^{6}$ Переверза О. Особливості процесуальної регламентації механізму формування показань 3 чужих слів і тактики допиту свідків та потерпілих, які дають такі показання (за КПК 2012 року). Юридичний науковий електронний журнал. 2015. № 2. С. 230.
} 
про нього зі слів іншої особи, має велике значення для встановлення істини. Значимість такого доказу дає додаткову та єдину можливість суду встановити істотні обставини для кримінального провадження. 3 огляду на викладене, показання осіб не можуть бути визнані недопустимим доказом лише на тій підставі, що вони є показаннями з чужих слів. Такий висновок було зроблено Верховним Судом України у постанові від 3 жовтня 2019 року № 138/3715/16-к. ${ }^{7}$

3 приводу ролі показань непрямих свідків у Європейському суді з прав людини (ССПЛ) зауважили, що іноді неоднозначний характер таких свідчень та ризик того, що особа може бути звинувачена та заарештована на основі неперевірених звинувачень, які не обов'язково $є$ неупередженими, не слід недооцінювати. 3 цих причин докази з чужих слів повинні бути підтверджені об'єктивними доказами. Це особливо актуально, коли приймається рішення про продовження тримання підозрюваного під вартою до судового розгляду. Хоча підозрюваний може бути справді затриманий на початку провадження на підставі тверджень непрямих свідків. Проте такі твердження обов'язково стають менш актуальними 3 плином часу, особливо коли в ході розслідування не було виявлено жодних додаткових доказів ${ }^{8}$. Також як приклад можна розглянути рішення ЄСПЛ у справі «Кавала проти Туреччини» ${ }^{9}$.

У рішення ЄСПЛ у справі «Лабіта проти Італії» йдеться про обвинувачення заявника у членстві в мафії, яке випливало лише з одного джерела, а саме свідчень колишнього мафіозі, який стверджував, що зі слів інших йому було відомо про членство заявника у мафії. У такому разі суд усвідомлював, що співпраця з колишніми мафіозі є важливою зброєю у боротьбі органів влади з мафією. Однак використання такої інформації, а також iї характер зумовлюють виникнення певних проблем, оскільки така інформація легко може стати предметом різноманітних маніпуляцій. Окрім того, вона може надаватися лише 3 огляду на можливість отримання певних пільг, які передбачені національним законодавством для осіб, що співпрацюють 3 органами влади, або 3 мотивів особистої помсти. Зважаючи саме на такі причини, національні суди визнали необхідність підтвердження такої інформації іншими доказами ${ }^{10}$.

\footnotetext{
7 Постанова Верховного Суду України від 03.10.2019 р. Справа № 138/3715/16-к. URL: https://ips.ligazakon.net/document/C011057 (дата звернення: 26.03.2020).

8 ЄСПЛ нагадав про критерії обгрунтованості підозри для арешту людини. URL: https://www.echr.com.ua/yespl-nagadav-pro-kriteri\%d1\%97-ob\%d2\%91runtovanosti-pidozri-dlya-areshtulyudini/ (дата звернення: 02.04.2020).

${ }^{9}$ Рішення ЄСПЛ у справі «Кавала проти Туреччини». URL: https://www.echr.com.ua/translation/spravakavala-proti-turechchini/ (дата звернення: 25.05.2020).

10 Рішення ЄСПЛ у справі «Лабіта проти Італії». URL: https://zakon.rada.gov.ua/laws/show/ 980_009/print (дата звернення: 19.04.2020).
} 
Отже, резюмуючи, можна стверджувати, що визнання судом показань 3 чужих слів допустимим доказом $є$ скоріш за все винятком з урахуванням певних умов, а не загальним правилом. 3 цього приводу автори науковопрактичного коментаря Кримінального процесуального кодексу України зазначають, що «в таких доказах закладена можливість помилки 3 причин суб'єктивного чинника. Вони формуються пізніше від первинних i на їх основі. Показання з чужих слів залежать не лише від змісту первинного джерела, а й від загальних закономірностей передачі і сприйняття інформації на кожному етапі ретрансляції. У разі передачі фактичних даних відбувається їх фільтрація і зміна. Отже, у їх змісті не виключається надмірна частка суб'єктивності» ${ }^{11}$.

Ми частково погоджуємося 3 цим твердженням і звертаємо увагу на те, що, незважаючи на всі ризики, які можуть виникати у разі використання слідчими показань з чужих слів під час досудового розслідування, а також суддями під час розгляду кримінальних проваджень у суді, натепер, як свідчить судова практика, показання з чужих слів широко використовуються як джерело доказу у слідчій та судовій практиці. При цьому проблемні питання використання показань 3 чужих слів виникають не тільки під час судового розгляду, а й під час досудового розслідування.

Слід зазначити, що недосконалість інституту визнання показань 3 чужих слів доказом призводить до звернення учасників кримінального провадження зі скаргою (в тому числі апеляційною), в якій ставиться питання про скасування вироку суду у зв'язку з тим, що в основу вироку покладені показання потерпілого і свідка з чужих слів, як це зазначено в Постанові Колегії суддів Другої судової палати від 30.05.2019 ${ }^{12}$.

Проте в зазначеному прикладі суд визнав допустимими доказами показання з чужих слів свідчення потерпілої та свідка $з$ тих підстав, що допитати безпосередньо потерпілого про обставини загибелі неможливо, оскільки він загинув, а надані показання узгоджуються з іншими доказами, наведеними у вироку суду.

Звичайно, під час вирішення такого питання необхідно перш за все встановити, чи надаються або використовуються висловлювання іншої особи для доведення існування того факту, про який стверджується у переданому висловлюванні. На цьому наголосив Верховний Суд України

\footnotetext{
11 Науково-практичний коментар Кримінального процесуального кодексу України. URL. http://mego.info/\%D0\%BC\%D0\%B0\%D1\%82\%D0\%B5\%D1\%80\%D1\%96\%D0\%B0\%D0\%BB/\%D1\%81\%D1 \%82\%D0\%B0\%D1\%82\%D1\%82\%D1\%8F-97-\%D0\%BF\%D0\%BE\%D0\%BA\%D0\%B0\%D0\%B7\%

D0\%B0\%D0\%BD\%D0\%BD\%D1\%8F-\%D0\%B7-\%D1\%87\%D1\%83\%D0\%B6\%D0\%B8\%D1\%85-\%D1\%81\% $\mathrm{D} 0 \% \mathrm{BB} \% \mathrm{D} 1 \% 96 \% \mathrm{D} 0 \% \mathrm{~B} 2$ (дата звернення: 01.04.2020).

12 Тижневий огляд судової практики Касаційного кримінального суду у складі Верховного Суду. URL: https://supreme.court.gov.ua/userfiles/media/Oglyad_KKS_27_05_19.pdf?fbclid=IwAR2Z-

o7ofhiIJxTI1KPYVuueMDPG-MBxU4SAwUx9yK1QT16baKGbZJg3L74 (дата звернення: 07.05.2020).
} 
під час розгляду справи № 441/845/17 (постанова ККС ВС від 19 листопада 2019 року). Позаяк показання, які містять висловлювання іншої особи, надані 3 іншою метою, наприклад, для доведення того, що інша особа висловилася саме так за певних обставин, не можуть вважатися показаннями з чужих слів відповідно до ст. 97 КПК України, оскільки у такому разі вони $\epsilon$ повідомленням про факт висловлювання, який свідок безпосередньо спостерігав ${ }^{13}$.

Звісно, у змісті показань з чужих слів не виключається частка суб'єктивності. Водночас, як слушно зазначають автори науково-практичного коментаря КПК України, необхідність в їх отриманні може виникати у таких випадках: 1) коли значимість такого доказу надає додаткову і єдину можливість суду встановити істотні обставини для кримінального провадження, а також коли без наявності такого доказу неможливо довести необхідну обставину для провадження; 2) якщо використання такого доказу є виправданим у ситуації відсутності первинних доказів або їх сумнівності; 3) коли первинний доказ втрачений або його неможливо отримати; 4) коли за допомогою показань 3 чужих слів $\epsilon$ можливість віднайти інші докази, до яких слід звернутися для перевірки фактів, що мають значення для провадження; 5) коли дані, отримані з чужих слів, можуть слугувати засобом перевірки інших доказів кримінального провадження; 6) коли показання з чужих слів може використовуватися як засіб заміни первинного доказу ${ }^{14}$.

Отже, йдеться про виняткові випадки використання показань з чужих слів як доказів у кримінальному провадженні, а не загальне правило. Так, у ч. 2 ст. 97 КПК України зазначено, що суд має право визнати допустимим доказом показання з чужих слів незалежно від можливості допитати особу, яка надала первинні пояснення, у виняткових випадках, якщо такі показання $€$ допустимим доказом згідно з іншими правилами допустимості доказів. На нашу думку, поняття винятковості, як оціночне, має тлумачитися у кожному конкретному випадку, виходячи з конкретних обставин i умов, а оцінка такого доказу повинна проводитись на принципах справедливості та розумності. Такі докази мають насамперед відповідати вимогам, викладеним у ст.ст. 84-89 КПК України, а також спеціальним вимогам. 3 огляду на те, що в показаннях з чужих слів закладена велика вірогідність бути помилковими, адже їх зміст залежить від загальних закономірностей передачі і суб'єктивного сприйняття

\footnotetext{
13 Постанова Верховного Суду України від 19.11.2019 р. Справа № 441/845/17, провадження № 51-8328км18. URL: http://reyestr.court.gov.ua/Review/85934761?fbclid=IwAR35qetlrA36E_rB37ktT 1jYb7HmAnLorTT5aZofj8C5k5wYDWQ-imemtd4 (дата звернення: 04.05.2020).

14 Кримінальний процесуальний кодекс України : науково-практичний коментар / за заг. ред. В.Г. Гончаренка, В.Т. Нора, М.С. Шумила. Київ : Юстініан, 2012. С. 267.
} 
інформаці1і ${ }^{15}$, законодавець визначив особливі правила оцінки допустимості таких показань.

3 огляду на викладене вище слід зазначити, що показання з чужих слів не $\epsilon$ самостійним джерелом доказів, адже у будь-якому разі такі показання мають бути підтверджені іншими доказами, визнаними допустимими згідно з правилами, відмінними від положень ч. 2 ст. 97 КПК України. Вони не можуть бути вирішальними та єдиними під час винесення судового рішення. Проте вважаємо, що показання 3 чужих слів $є$ необхідним джерелом доказів у виняткових випадках. Вони надають додаткову можливість суду встановити факт чи обставини, які є предметом дослідження у кримінальному провадженні. Крім того, як свідчить зарубіжний досвід, показання, засновані на чутках, у певних випадках мають велике значення для встановлення істини у справі, будучи «найкращим доступним» джерелом доказів ${ }^{16}$, зокрема у разі відсутності чи обмеженої кількості первинних доказів, втрати можливості отримати докази з первинного джерела тощо.

\section{2. Особливості визнання показань 3 чужих слів доказом}

Під час впровадження інституту показань з чужих слів у КПК України фахівці намагалися використати зарубіжний досвід використання у кримінальному провадженні показань з чужих слів як джерела доказів. Але, незважаючи на намагання передбачити всі проблемні аспекти, що виникають на практиці, залишилася низка невирішених і неврегульованих питань.

Перш за все слід звернути увагу на недосконалість визначення поняття «Показання 3 чужих слів», яке містить КПК України. Поширеним в іноземних державах $є$ подання саме письмових доказів через свідків, які дають свідчення про достовірність відомостей у цих матеріалах. Так, за кримінальним процесуальним законодавством США до показань 3 чужих слів належить будь-яка інформація, яка не стосується особистих знань свідка, а є отриманою від третіх осіб. Така заява свідка зазвичай тягне за собою заперечення захисника іншої сторони i суд може заборонити присяжним брати цю заяву до уваги. Однак із загального правила недопустимості показань $з$ чужих слів як доказів $є$ виняток, це: заява особи, що перебуває на межі смерті; спонтанні вислови - вислови, які

\footnotetext{
15 Кримінальний процесуальний кодекс України : науково-практичний коментар: у 2 т. / О.М. Бандурка, Є.М. Блажівський, Є.П. Бурдоль та ін. ; за заг. ред. В.Я. Тація, В.П. Пшонки, А.В. Портнова. Харків : Право, 2012. Т. 1. С. 274.

${ }^{16}$ The Law Commission Report on "Evidence in criminal proceedings: hearsay and related topics". URL: http://www.lawcom.gov.uk/wp-content/uploads/2015/03/lc245_Legislating_the_Criminal_Code_Evidence_in_ Criminal_Proceedings/pdf/.
} 
особа робить у запалі, не маючи часу на їх обдумування; заяви, зроблені свідком поза залою суду і письмово чи іншим чином зафіксовані (такі заяви можуть бути представлені як докази за умови, що свідок у суді підтвердить їх достовірність); заяви третіх осіб, які можуть викрити їх у вчиненні протиправного діяння; документи, записи, свідоцтва тощо ${ }^{17}$. Натомість визначення, яке міститься у ч. 1 ст. 97 КПК України (словосполучення «яке грунтується на поясненні іншої особи»), на переконання В. Точиловського, не дає відповіді на питання, чи підпадають під цю категорію такі, наприклад, поширені види доказів:

- показання в суді свідка про зміст документа, який він читав, але автором якого не є. Якщо такі показання допускаються, то виникне питання приймати як доказ (після завершення допиту) тільки показання свідка про документ або свідчення разом з документом;

- показання в суді експерта-криміналіста з приводу документа, який він досліджував (наприклад, на предмет можливої підробки), але автором якого (документа) він не є. Те ж саме про документ, про який свідчив експерт - допускається він як доказ на підставі показань експерта;

- представлені через свідків у суді «бізнес-документи» (платіжки, контракти і т.д.), автори яких не викликаються як свідки;

- представлені через свідків у суді письмові висновки експертів, які не викликаються до суду як свідки;

- документи, що подаються стороною для залучення як доказу (evidence from the bar table $)^{18}$.

На підставі зазначеного автор пропонуе в майбутньому у разі тлумачення (або зміни) ст. 97 КП використовувати визначення hearsay, що застосовуються в англомовних нормативних документах (наприклад, ст. 801 Federal Rules of Evidence США) ${ }^{19}$.

Порівнюючи законодавство США та Великобританії, варто звернути увагу, що в кримінальному процесі зазначених країн передбачена можливість визнання допустимим доказом показань з чужих слів, якщо вони даються слідчим, прокурором, співробітником оперативного підрозділу або іншою особою стосовно пояснень осіб, наданих зазначеним особам під час здійснення ними кримінального провадження. Особливе місце в англійському праві займає визнання вини обвинуваченого, яке було повідомлене третім особам, зокрема посадовій особі правоохоронних

${ }^{17}$ Carmen Rolando V. del. Criminal Procedure: Law and Practice. 2nd ed. Pacific Grove, California : Brooks/Cole publ., 1991. P. 377.

${ }^{18}$ В. Точиловский Определение «показаний с чужих слов» (hearsay) в новом УПК Украины. URL: http://interjustice.blogspot.com/2012/12/hearsay.html.

19 Definitions That Apply to This Article; Exclusions from Hearsay (Rule 801). URL: https://www.law.cornell.edu/rules/fre/rule_801. 
органів. Умовами їх допустимості $\epsilon$ добровільність такої заяви та дотримання прав цієї особи ${ }^{20}$.

Водночас у ч. 7 ст. 97 КПК України зазначено, що у будь-якому разі не можуть бути визнані допустимим доказом показання з чужих слів, якщо вони даються слідчим, прокурором, співробітником оперативного підрозділу або іншою особою стосовно пояснень осіб, наданих слідчому, прокурору або співробітнику оперативного підрозділу під час здійснення ними кримінального провадження. На думку В. Лушпієнка, в умовах українських реалій таке положення є цілком виправданим. Проте іншої думки А. Панова, Н. Скідан, які вважають, що «справді, слідчий, прокурор, співробітник оперативного підрозділу як сторона обвинувачення можуть бути упередженими у такій ситуації, проте інша особа, яка розуміється як третя особа, не має власного процесуального інтересу». На підтвердження своєї думки автори наводять приклад, коли особа, яка $\epsilon$ першоджерелом, 3 власних мотивів та за власним бажанням, ураховуючи ситуацію, що склалася, повідомляє певну інформацію співробітникам органу досудового розслідування, свідком чого стала інша особа у розумінні ч. 7 ст. 97 КПК України ${ }^{21}$. 3 огляду на те, що слідчий, прокурор, співробітник оперативного підрозділу безпосередньо сприймали інформацію від першоджерела, то такі показання інших осіб можуть бути допоміжним засобом встановлення обставин кримінального провадження.

3 огляду на зазначене вище та поділяючи думку А. Панової, Н. Скідан, вважаємо необхідним передбачити в КПК України можливість використання показань з чужих слів, що даються іншою особою, якщо ӥй стала відома інформація від першоджерела, навіть за умови, що ці відомості передавалися не їй, а слідчому, прокурору чи співробітнику оперативного підрозділу ${ }^{22}$.

Досліджуючи питання допустимості доказів, I. Чупрікова зазначає, що протягом дії КПК України вже стає очевидною необхідність удосконалення його норм щодо допустимості доказів, зокрема, щодо забезпечення прав сторони захисту зі збирання доказів, можливості давати показання 3 чужих слів малолітніми особами тощо. Крім того, у правозастосовній практиці накопичилося чимало питань стосовно застосування норм КПК щодо допустимості доказів, які потребують вирішення на законодавчому рівні ${ }^{23}$.

\footnotetext{
20 Лушпієнко В. Показання з чужих слів за законодавством України та іноземних держав. URL: file:///C:/Users/PS/Downloads/nvuzhpr_2017_43(2)__41.pdf.

${ }^{21}$ Панова А., Скідан Н. Окремі питання використання показань з чужих слів у кримінальному процесі України. URL: http://jurnaluljuridic.in.ua/archive/2018/6/part_1/44.pdf.

${ }^{22}$ Там само.

${ }^{23}$ Чупрікова І. Допустимість доказів у світлі нового кримінального процесуального кодексу : автореф. дис. ... канд. юрид. наук. Одеса, 2016. С. 1-2.
} 
3 метою вирішення зазначеної проблеми автор вказує на доцільність нормативного визначення кола осіб, які можуть давати показання з чужих слів, зокрема, запропоновано встановити обмеження можливості дачі показань з чужих слів для малолітніх осіб та осіб похилого віку, які через свої психологічні та фізіологічні особливості не можуть повною мірою давати оцінку почутому та побаченому ${ }^{24}$.

3 цього приводу слід зазначити, що КПК України не встановлює заборони щодо певної категорії осіб, які можуть давати показання з чужих слів. Винятки із цього правила передбачені законодавцем в ч. 7 ст. 97 КПК України. Отже, всі інші особи, в тому числі і малолітні та неповнолітні, можуть давати показання з чужих слів. Проте у такому разі необхідно врахувати визначені в ст. 226 КПК України особливості допиту малолітніх або неповнолітніх осіб. А саме допит малолітньої або неповнолітньої особи проводиться у присутності законного представника, педагога або психолога, а за необхідності - лікаря. Також особам, які не досягли шістнадцятирічного віку, роз'яснюється лише обов'язок про необхідність давання правдивих показань, і така категорія осіб не попереджається про кримінальну відповідальність за відмову від давання показань і за завідомо неправдиві показання.

3 урахуванням такої норми КПК України слід погодитися із I. Чупріковою, яка зазначає, що викликає заперечення можливість давання малолітніми або неповнолітніми особами показань 3 чужих слів, оскільки: «по-перше, на них можуть здійснювати вплив як законні представники, педагоги, так і безпосередньо особа, яка надає первинні показання. Подруге, така категорія осіб ще не пройшла всіх етапів соціальної формації, іiі світосприйняття може бути спотворене як власними уявленнями, так i зовнішніми страхами або іншими факторами. У зв'язку з цим запропоновано доповнити ст. 97 КПК положенням про заборону давати показання 3 чужих слів малолітніми особами ${ }^{25}$. Що, на нашу думку, $\epsilon$ суперечливим.

Також досить складною є ситуація у випадку, коли потерпілою є дитина. Для прикладу розглянемо кримінальне провадження, у якому потерпілій на момент вчинення злочину ще не виповнилося 4 роки, і обвинувачення за кримінальним провадженням, крім iï показань, грунтується на показаннях потерпілої, показаннях з чужих слів або на показаннях про показання 3 чужих слів.

\footnotetext{
${ }^{24}$ Там само. С. 2.

${ }^{25}$ Чупрікова І. Допустимість доказів у світлі нового кримінального процесуального кодексу : автореф. дис. ... канд. юрид. наук. Одеса, 2016. С. 9-10.
} 
У такому разі суд першої інстанції грунтував свій висновок про винуватість засудженого лише на одному доказі - показаннях потерпілої. Потерпіла - дитина, якій, як ми вже зазначали, на момент інкримінованої події було 3 роки і 10 місяців, а на час давання показань у суді - 4 роки. Потерпіла давала показання через 2 місяця після події і іiі показання супроводжувалися час від часу коментарями психолога, присутнього на допиті, про те, що вона фантазує. Решта доказів, наведених в обвинувальному вироку на підтвердження самої події, умислу засудженого i інших елементів складу злочину, $є$ показаннями 3 чужих слів або показаннями про показання з чужих слів, приправленими - для додаткової переконливості - відомостями щодо характеру та окремих рис особи засудженого, також недопустимими на доведення винуватості ${ }^{26}$.

Як приклад можна навести йі інші кримінальні провадження, де процес доказування побудовано переважно на показаннях обвинуваченого i потерпілого та показаннях з чужих слів. Відповідно, необхідно звернути увагу на той факт, що показання з чужих слів можуть грунтуватися на даних, які стали відомими особі від іншої, яка не є першоджерелом цієї інформації, тобто їй ці дані стали відомі ще від однієї особи. Тому варто зазначити, що слідчий, i, відповідно, суд у майбутньому під час прийняття рішення у кримінальному провадженні повинен враховувати ту обставину, що, крім потерпілого й обвинуваченого, інших свідків події немає, тому кінцеве рішення по таких кримінальних провадженнях буде грунтуватися на показаннях обвинуваченого, потерпілого та показань 3 чужих слів. Проте в такому разі необхідно врахувати положення ч. 6 ст. 97 КПК України, якою передбачено, що показання з чужих слів не може бути допустимим доказом факту чи обставин, на доведення яких вони надані, якщо показання не підтверджуються іншими доказами, визнаними допустимими згідно 3 правилами, відмінними від положень ч. 2 ст. 97 КПК України. Тобто зазначеною нормою КПК України чітко передбачено, що показання свідка, надані ним з чужих слів, повинні в обов'язковому порядку підтверджуватись й іншими допустимими доказами у кримінальному провадженні.

Також на практиці трапляються випадки, коли свідок у кримінальному провадженні дає показання з чужих слів, які є показаннями іншого свідка, який під час досудового розслідування неодноразово змінював свої показання і такі показання не підтверджуються іншими доказами у цьому провадженні ${ }^{27}$. Надалі як результат судового розгляду по такому

\footnotetext{
${ }^{26}$ Окрема думка судді Бущенка А.П. до постанови колегії суддів Касаційного кримінального суду Верховного Суду від 05.06.2018 р. у провадженні № 51-2329км18 (справа № 360/1378/16-к). URL: http://reyestr.court.gov.ua/Review/74777453 (дата звернення: 27.03.2019).

27 Ухвала Ізюмського міськрайонного суду Харківської області від 28.10 .2015 p. URL: http://reyestr.court.gov.ua/Review/52840715 (дата звернення: 27.03.2020).
} 
кримінальному провадженню ці показання в процесі оцінки судом усіх доказів під час постановки рішення можуть бути визнані як недопустимий доказ.

Отже, виходячи із поняття «належність доказів», слід зазначити, що «використання показань 3 чужих слів повинно відбуватися за правилами застосування непрямих доказів. Видається, що такі докази не можуть достовірно встановлювати спірні факти. На одних лише показаннях 3 чужих слів не можуть грунтуватися підозра та обвинувачення, тільки в сукупності з первинними доказами вони можуть визнаватися достатніми для прийняття судових рішень» ${ }^{28}$.

\section{ВИСНОВКИ}

Отже, з огляду на викладене вище, вважаємо, що інститут показань 3 чужих слів в Україні $є$ доцільним і можливим 3 урахуванням його доопрацювання й удосконалення. Не слід визнавати недопустимими докази лише на тій підставі, що вони є показаннями з чужих слів, але у будь-якому разі такі показання мають бути підтверджені іншими доказами, визнаними допустимими згідно з правилами, відмінними від положень ч. 2 ст. 97 КПК України.

У процесі здійснення своїх повноважень суди повинні відійти від упередженої думки, що підсудний вчинив злочинне діяння, позаяк обов'язок доведення цього лежить на обвинуваченні та будь-який сумнів трактується на користь підсудного, а тому проголошує право особи на презумпцію невинуватості. В основі цього права лежить принцип, згідно 3 яким особа, яку обвинувачують у вчиненні кримінального правопорушення, має право на виправдувальний вирок у разі нестачі доказів проти неї i тягар подання достатніх доказів для доведення вини покладається на сторону обвинувачення.

Відповідно, надаючи оцінку всім доказам винуватості особи у вчиненні злочину, у їх сукупності суди повинні враховувати практику ЄСПЛ, відповідно до якої необхідно оцінювати докази, керуючись критерієм доведення «поза розумним сумнівом». Також має враховуватись якість доказів, включаючи те, чи не ставлять обставини, за яких вони були отримані, під сумнів їхню надійність та точність.

Аналіз судових рішень дає підстави стверджувати, що в українському судочинстві під час прийняття рішення про визнання показань з чужих слів допустимим доказом судді мотивують свої рішення наявністю інших

\footnotetext{
28 Кримінальний процесуальний кодекс України : науково-практичний коментар / За загальною редакцією професорів В.Г. Гончаренка, В.Т. Нора, М.С. Шумила. Київ : Юстініан, 2012. 1224 с. С. 264.
} 
доказів, які їх підтверджують, і які відповідно визнані допустимими згідно 3 правилами, відмінними від положень ч. 2 ст. 97 КПК України.

Незважаючи на те, що згідно з ч. 2 ст. 97 КПК України лише суд має право визнати допустимим доказом показання з чужих слів, проте слідчий під час досудового розслідування також наділений повноваженням викликати і допитувати свідка, підозрюваного, потерпілого або іншого учасника кримінального провадження для допиту. Відповідно, такі показання будуть використовуватися як доказ на стадії досудового розслідування під час прийняття слідчим процесуального рішення.

Ст. 97 КПК України визначено порядок визнання допустимим доказом показання 3 чужих слів судом. 3 чим ми не можемо погодитися 3 урахуванням того, що значна частина доказів по кримінальному провадженню формує доказову базу саме під час досудового розслідування, відповідно, надалі, якщо суд прийме рішення про визнання показань 3 чужих слів недопустимим доказом, це може призвести до визнання недопустимими інших доказів, які зібрані під час досудового розслідування у разі прийняття слідчим процесуального рішення.

Проте в КПК України відсутня норма, яка б визначала, за якими критеріями слідчий повинен оцінити показання з чужих слів як доказ 3 точки зору належності, допустимості, достовірності. Судячи з положення ст. 94 КПК України, за загальним правилом, яке стосується всіх доказів по кримінальному провадженню, слідчий за своїм внутрішнім переконанням повинен визначити такі критерії, як належність, допустимість, достовірність показань 3 чужих слів. 3 урахуванням цього вважаємо, що КПК України необхідно доповнити статтею, яка б чітко визначала, за яких умов слідчий може використовувати під час досудового розслідування показання 3 чужих слів як доказ у разі прийняття ним процесуального рішення.

\section{АНОТАЦІЯ}

У статті досліджено проблемні питання щодо визнання показань 3 чужих слів доказом у кримінальному процесі України. Акцентовано увагу на тому, що порядок використання показань 3 чужих слів під час досудового розслідування та розгляду справи в суді має низку неузгодженостей. Розглянуто погляди вчених щодо особливостей дачі показань з чужих слів малолітніми особами та особами похилого віку, які через свої психологічні та фізіологічні особливості не можуть повною мірою давати оцінку почутому та побаченому. Вивчено досвід зарубіжних країн щодо можливості визнання показань 3 чужих слів допустимим доказом, якщо вони даються слідчим, прокурором, співробітником оперативного 
підрозділу або іншою особою стосовно пояснень осіб, наданих зазначеним особам під час здійснення ними кримінального провадження. Звертається увага на те, що в КПК України відсутня норма, яка б визначала, за якими критеріями слідчий повинен оцінити показання з чужих слів як доказ 3 точки зору належності, допустимості, достовірності. На підставі аналізу слідчої практики, рішень суду та ЄСПЛ зроблено висновок про те, що не слід визнавати докази недопустимими лише на тій підставі, що вони $є$ показаннями з чужих слів, але у будь-якому разі такі показання мають бути підтверджені іншими доказами. Зазначається про необхідність удосконалення правового регулювання інституту показань з чужих слів.

\section{ЛІТЕРАТУРА}

1. Конвенція про захист прав людини і основоположних свобод : підпис. 4 лист. 1950 р., м. Рим ; ред. від 02 жовт. 2013 р. ; ратифіковано Законом України від 17 черв. 1997 р. № 475/97-BP. / Верховна Рада України. URL: https://zakon.rada.gov.ua/laws/show/995_004 (дата звернення: 21.05.2020).

2. Науково-практичний коментар Кримінально-процесуального кодексу України. URL: http://mego.info/\%D0\%BC\%D0\%B0\%D1\%82\% D0\%B5\%D1\%80\%D1\%96\%D0\%B0\%D0\%BB/\%D1\%81\%D1\%82\%D0\%B0\% D1\%82\%D1\%82\%D1\%8F-97-\%D0\%BF\%D0\%BE\%D0\%BA\%D0\%B0\%D0\% B7\%D0\%B0\%D0\%BD\%D0\%BD\%D1\%8F-\%D0\%B7-\%D1\%87\%D1\%83\% D0\%B6\%D0\%B8\%D1\%85-\%D1\%81\%D0\%BB\%D1\%96\%D0\%B2 （дата звернення: 01.04.2020).

3. Король В. Садова Т. Показання як джерело доказів у кримінальному провадженні. Науковий вісник Дніпропетровського державного університету внутрішніх справ. Дніпропетровськ. 2013. № 3.С. 428-434.

4. Комітет $з$ питань верховенства права та правосуддя рекомендує парламенту направити на доопрацювання проєкт закону про внесення змін до Кримінального процесуального кодексу України (щодо виключення положень про визнання доказами показань 3 чужих слів). URL: https://rada.gov.ua/fsview/78466.html (дата звернення: 07.04.2020).

5. Про внесення зміни до Кримінального процесуального кодексу України (щодо виключення положень про визнання доказами показань 3 чужих слів) : проєкт Закону України від 28.01.2013 p. № 2112. URL: https://ips.ligazakon.net/document/view/jg1mo00i?ed=2013_01_28 (дата звернення: 26.05.2020).

6. Переверза О. Особливості процесуальної регламентації механізму формування показань з чужих слів і тактики допиту свідків та потерпілих, які дають такі показання (за КПК 2012 року). Юридичний науковий електронний журнал. 2015. № 2. С. 228-230. 
7. Постанова Верховного Суду України від 03.10.2019 р. Справа № 138/3715/16-к. URL: https://ips.ligazakon.net/document/C011057 (дата звернення: 26.03.2020).

8. ССПЛ нагадав про критерії обгрунтованості підозри для арешту людини. URL: https://www.echr.com.ua/yespl-nagadav-pro-kriteri\%d1\%97-ob\% d2\%91runtovanosti-pidozri-dlya-areshtu-lyudini/ (дата звернення: 02.04.2020).

9. Рішення ЄСПЛ у справі «Кавала проти Туреччини». URL: https://www.echr.com.ua/translation/sprava-kavala-proti-turechchini/ (дата звернення: 25.05.2020).

10. Рішення ЄСПЛ у справі «Лабіта проти Iталії». URL: https://zakon.rada.gov.ua/laws/show/980_009/print (дата звернення: 19.04.2020).

11. Тижневий огляд судової практики Касаційного кримінального суду у складі Верховного Суду. URL: https://supreme.court.gov.ua/userfiles/ media/Oglyad_KKS_27_05_19.pdf?fbclid=IwAR2Z-o7ofhiIJxTI1 KPYVuueMD PG-MBxU4SAwUx9yK1QT16baKGbZJg3L74 (дата звернення: 07.05.2020).

12. Постанова Верховного Суду України від 19.11.2019 р. Справа № 441/845/17, провадження № 51-8328км18. URL: http://reyestr.court.gov.ua/ Review/85934761?fbclid=IwAR35qetlrA36E_rB37ktT1jYb7HmAnLorTT5aZof j8C5k5wYDWQ-imemtd4 (дата звернення: 04.05.2020).

13. Кримінальний процесуальний кодекс України : науково-практичний коментар / за заг. ред. В.Г. Гончаренка, В.Т. Нора, М.С. Шумила. Київ : Юстиніан, 2012. 1224 c.

14. Кримінальний процесуальний кодекс України : науково-практичний коментар: у 2 т. / О.М. Бандурка, Є.М. Блажівський, Є.П. Бурдоль та ін. ; за заг. ред. В.Я. Тація, В.П. Пшонки, А.В. Портнова. Харків : Право, 2012. T. $1.768 \mathrm{c}$.

15. The Law Commission Report on "Evidence in criminal proceedings: hearsay and related topics". URL: http://www.lawcom.gov.uk/wpcontent/uploads/2015/03/lc245_Legislating_the_Criminal_Code_Evidence_in_ Criminal_Proceedings/pdf/.

16. Carmen Rolando V. del. Criminal Procedure: Law and Practice. 2nd ed. Pacific Grove, California : Brooks/Cole publ., 1991. P. 377. 483 p.

17. Точиловский В. Определение «показаний с чужих слов» (hearsay) в новом УПК Украины. URL: http://interjustice.blogspot.com/2012/12/ hearsay.html.

18. Definitions That Apply to This Article; Exclusions from Hearsay (Rule 801). URL: https://www.law.cornell.edu/rules/fre/rule_801.

19. Лушпієнко В.М. Показання з чужих слів за законодавством України та іноземних держав. URL: file://C:/Users/PS/Downloads/nvuzhpr_2017_ 43(2)_441.pdf. 
20. Панова А., Скідан Н. Окремі питання використання показань з чужих слів у кримінальному процесі України. URL: http:/jurnaluljuridic.in.ua/ archive/2018/6/part_1/44.pdf.

21. Чупрікова І.Л. Допустимість доказів у світлі нового кримінального процесуального кодексу : автореф. дис. ... канд. юрид. наук. Одеса, 2016. 23 с.

22. Окрема думка судді Бущенка А.П. до постанови колегії суддів Касаційного кримінального суду Верховного Суду від 5 червня 2018 року у провадженні № 51-2329км18 (справа № 360/1378/16-к) URL: http://reyestr.court.gov.ua/Review/74777453 (дата звернення: 21.04.2020).

23. Ухвала Ізюмського міськрайонного суду Харківської області від 28 жовтня 2015 року. URL: http://reyestr.court.gov.ua/Review/52840715 (дата звернення: 27.04.2020).

\section{Information about authors:} Ponomarenko A. V.,

Candidate of Juridical Sciences (Ph.D.), Senior Researcher, Leading Researcher in the Research Laboratory of Problems of Legal and Organizational Support for the Ministry Activities

State Research Institute of the Ministry of Internal Affairs of Ukraine 4a, Gutsalo Lane, Kyiv, 01011, Ukraine Havryliuk L. V., Candidate of Juridical Sciences (Ph.D.), Senior Researcher at the Research Laboratory of Problems of Legal and Organizational Support for the Ministry Activities

State Research Institute of the Ministry of Internal Affairs of Ukraine 4a, Gutsalo Lane, Kyiv, 01011, Ukraine 